\title{
IMMIGRATION IN SPANISH NATION
}

Ana Caballero Mengibar

\section{INTRODUCTION}

The endurance of Spanish peripheral regionalisms dating to the 1800s has intrigued scholars for centuries, raising the question of whether Spain in fact has a national identity (Balfour and Quiroga, 2007; Beramendi, 1992; Linz, 1993; Muro and Quiroga, 2005: 25; Núñez, 1993; Núñez, 2001; Stapell, 2007). This contrasts with an abundance of scholarly literature on the topics of regional nationalisms, particularly historical regionalisms such as the Basque, Catalan, and Galician. Other non-exotic forms of regional or peripheral nationalisms, such as in Andalucia, Valencia, and Aragon, have also received significantly more attention (Núñez, 1993). Flynn (2001: 712) suggests that the lack of interest in studying the Spanish identity as its own subject is also evident in the low number of bookstores that carry publications on this topic. Academic emphasis on peripheral nationalism from 1975 to the 1990s is arguably to blame for this dearth of historiography on the national question (Stapell, 2007). Other explanations may include the Spanish desire to quickly forget the long 40 years of oppressive, centralized, state-led national identity at the hands of Francisco Franco (1939-1975) and his authoritarian fascist regime, and to the Spanish nation's desire to transition to a successful democracy.

Contemporary migratory patterns have complicated this debate. Since the late 1990s, Spain has experienced 'the most rapid rate of immigration in the Western world' (Saunders, 2008: 1). A recent report from the Migration Policy Institute argues that 'immigration is not perceived as a threat to [the Spanish] national identity... it could also be surmised that Spanish nationalism is, in itself, under question' (Arango, 2013: 12). International migration caused by globalization has, as Castles and Miller (1998: 15) argue, increased diversity within societies, presenting a number of problems for the state. One of the most serious is the new challenge to national identity. This is more problematic for states in which ethnic 
homogeneity is imagined 'in terms of common language, culture, traditions and history'.

If claims hold that Spain does not have a national identity, but rather an amalgam of peripheral identities and nationalisms, it follows that recent migratory movements would present much less of a challenge to the Spanish state because allegedly a sense of pride in being Spanish and homogeneity in 'España' does not exist. However, recent changes in Spanish immigration law and changes in perceptions among spaniards about immigrants suggest otherwise. This new reality raises yet more questions about the Spanish national identity.

The case study of Spain provides a framework to help shed light on the question of how nationalism is formed by investigating whether contemporary immigration patterns provide enough cohesion to bind the nation and to re-imagine its national identity. It also serves to help explore whether nation building works via re-imagining a national horizontal fraternity, or Spanishness, and/ or selectively excluding certain groups that do not belong to the imaginary collective self. Contemporary immigration has shaped the discourse of Spanishness, such that an overarching national identity can now be identified in Spain. The imagining of a national identity is an ongoing process that involves codifying the difference between 'us' and 'them' (Doty, 2003). However, competing discourses of difference and belongingness, produced in a particular historical period of time, must be commonly accepted as legitimate threats to the existence of an imagined primordial identity to successfully bind the nation to a perceived common fate. Because nation building is never a finished process, discourses of belongingness and exclusion must coexist, competing daily to produce the national identity of Spain.

Competing historical narratives of Spanishness and 'otherness' have always existed in the discourse of nation formation in Spain; yet, they have failed to produce a univocal compelling argument of nationhood in Spain, thus preventing a horizontal fraternity among its people. This lack of a univocal, unified national identity before and after Franco should not be interpreted as the absence of identity but rather as the inability to produce compelling 
competing discourses of belongingness and 'otherness' capable of binding the Spanish nation. A Spanish national identity, although multifaceted, can nevertheless be identified.

\section{THEORY OF NATION BUILDING}

Scholars continue to struggle to analyze and define nation-building processes (Anderson 1983; Bishop and Jaworski, 2003). Benedict Anderson introduced the innovative term 'imagined community' in 1983, defining it as a horizontal comradeship; he further explained that the cultural roots of nationalism lie in this horizontal fraternity. According to Anderson (1983: 7), 'ultimately it is this fraternity that makes it possible, over the past two centuries, for so many millions of people, not so much to kill, as willingly to die for such limited imaginings'. Anderson's (1986) argument spoke particularly about the role of the mass-print of capitalism as a means to construct a unit of identification for the nation - larger than a region, village, or local community. Successful nation building therefore requires construction of a horizontal comradeship.

In a compelling argument, Anthony Marx (2003) proposes that modern European nationalisms emerged as a form of mass political engagement based upon religion, conflict, intolerance, and exclusion. Discourses of exclusion, which coexist with discourses of belongingness, must have enough 'torque' (Marx, 2003) to successfully nationalize the people. The kind of horizontal fraternity that Anderson proposes is not always attainable. The right types of competing discourses of inclusion and exclusion must not only coexist but must gain enough strength against each other to create a sense of unity and belonging to the nation.

Contemporary theories of 'neo-racism' argue that labeling certain social groups as 'culturally incompatible' has led to more contemporary forms of exclusion. Samuel Pehrson and Eva Green (2010: 696) posit that

host nationals can demarcate boundaries between themselves and immigrants (1) by defining the national group membership, whereby the focus is on the in-group, as well as (2) by endorsing entry criteria for incoming immigrants, which more directly pertains to perceptions of the out-group. 
According to Balibar (1991: 21),

the dominant theme is not biological heredity but the insurmountability of cultural differences, a racism which, at first sight, does not postulate the superiority of certain groups or peoples in relation to other groups but 'only' the harmfulness of abolishing frontiers, and the incompatibility of life-styles and traditions.

The increasing migration of people around the world, as a product of globalization, makes 'neo-racialized' theories an interesting option for investigating how processes of inclusion and exclusion of immigrants and nationals work together in the making of a nation. In contemporary Western democracies, neo-racialized formations of immigrants from less-developed countries may contain the necessary torque to bind the nation in a time when global interdependence is at its highest.

A sound theoretical approach, therefore, views nation building as the product of competing, sometimes contradictory discourses of inclusion and exclusion. Such narratives can however also lead to fragmented nations or states if they do not have enough binding 'torque' (Marx, 2003). Exclusionary narratives and practices aligned with immigration are particularly interesting units of analysis because they inherently possess the kind of 'torque' necessary to build the horizontal fraternity that is at the root of the origins of nationalism (Anderson, 1983).

\section{OVERVIEW OF COMPETING DISCOURSES ON NATION BUILDING IN SPAIN}

From the unification of Spain in the early 1500s to the early 1800s, Spanish identity had been constructed around attributes of the 'true' religion (Roman Catholic), loyalty to the monarch, and primordial ethnicity. These constructions became apparent shortly after the unification reached by the Catholic kings under the rule of Habsburg Charles V and Philip II (Álvarez Junco, 2002: 15). 'Spanishness' was imagined as the product of having a unique history, culture, and geographical features. According to Álvarez Junco (2002: 21), the argument presented by the elites was that 'since time immemorial 'Spaniards' had survived wave after wave 
of invaders, in successive cycles of loss and recovery of the national personality'.

By the early 1800s, Spanish intellectual elites sought to re-imagine the identity of Spain by inspiring a revitalized nationalism, toward the final end of modernizing the society and its political system. At that time, following European models, liberal values encompassing the principles of modernity, secularism, and liberalism were introduced into the political discourse with the overall goal of establishing Spain as a true modern nation-state. Asturian congressman Agustin Arguelles claimed victory during his introduction of the first liberal Spanish constitution of 1812 when he said, 'Spaniards, you now have a nation' (Álvarez Junco, 2001).

From the start, these modern liberal values were unsettling in a nation that for so long had aligned itself with Catholicism and monarchy. A unified Spain under liberal principles modeling its European counterparts was not yet sustainable. It would not be long before Fernando VII's revocation of the liberal constitution forced liberal intellectuals to flee the country, and Catholic and monarchical values were re-legitimized as the core values of the Spanish nation (Labanyi, 2004: 230).

As evidenced in the many liberal revolutions of that century, the liberals were not deterred by this first defeat. The history of nineteenth-century Spain and beyond was marked by deep internal political crises. Spain experienced three civil wars in the nineteenth century and another terrible war in the twentieth century (Álvarez Junco, 2002: 23). After the Napoleonic wars of the early nineteenth century, Spain's political power was significantly degraded. It was obvious that Spain was not at peace with the rest of Europe.

Since the Enlightenment, the other European nations had been constructing identity using the rhetoric of 'superiority of European identity' (Labanyi, 2004: 231). Being unable to participate in this European discourse, perceptions of backwardness and lack of economic and political progress and modernization became prevalent inside and outside of Spain. The more industrialized regions within Spain, namely the Basque and Catalonian regions, associated the lack of Spanish progress with a sense of 'failure' instead of pride in being Spanish (Álvarez Junco, 2002: 24). These two regions 
began a process of discursive separation, following different paths of identity formation. They sought to re-define themselves as being distinctly different from the rest of Spain.

A rejection of Spanishness was further reinforced by the abundance of diverse regional traditions and festivities, while Spain had a weak process for the creation of binding national symbols and myths. Anderson (1983) has shown that the mass printing of national news read daily across the nation was crucial for the formation of modern nationalisms. Spain had few national newspapers and the national flag was not established until 1843 (Álvarez Junco, 2001).

In the twentieth century General Franco orchestrated a coup to 'stop the tide of liberalism, secularism and modernization in Spain' (Jeram, 2013: 1775; see also Casanova, 2010; Graham, 2005). The establishment of Francisco Franco's authoritarian regime in Spain after a bloody civil war in the mid 1930s (1936-39) further deepened the crisis of national identity. Competing narratives of nation building - modernization, the true religion, and European and monarchical values - became a serious problem. While Franco was aiming to construct a centralized and militarized supra-national identity, various regions of Spain, notably the Basque Country and Catalonia, were struggling to define their own sub-national identity. Franco believed that the resurgence of Basque and Catalan nationalism constituted a threat not only to the hegemony of Spain but also to the construction of a Castile (pure) ethnic nation, so he attempted to suppress these regional identities (Muro and Quiroga, 2005: 18).

Not only did Francoist fascist policies forcefully suppress any expression of regional identification, including prohibiting the use of regional languages, but they discouraged any comparisons of Spain with Western Europe. This further deterred scholars from seriously studying the national identity of Spain, which contributed to the lack of literature on the subject.

Franco asserted that Spain was different (Carr, 2000:9). He argued that Spain's primordial and cultural traditions mandated a 'political trajectory based upon authoritarian national unity and its Catholic heritage' (González Anton, 1998: 612-613). 
Unquestionably, Franco's repressive yet weak tools for nationalizing the masses deeply marked a country that had dealt with problems of identification and with the idea of 'España' arguably since the nineteenth century (Álvarez Junco, 2002: 32).

The creation of a newly democratic Spanish nation-state after the death of Francisco Franco required both compromise and an effort to forget the common repressive past. Instead of fostering a collective national memory based on shared abuses suffered under the fascist regime to build unity, Francoist reformers and the opposition mandated a closure of the remembered past, as formalized by the Amnesty Acts of 1976 and 1977 (Flynn, 2001: 707). The social and political amnesia that has encapsulated Spain since the death of Franco, deterring national unity in favor of regional identification, was imagined under the promise of greater prosperity by increasing relations with the European community. Spain was now re-imagined as a more secular, pluralistic nation, composed of multiple regional identities, sharing little homogenous fraternity, and ready to embrace democratic values.

Symbols such as the Spanish flag and national anthem would continue to be associated with a repressive centralized Francoist national identity even after the transition to democracy. A 'Nation of Nations' was the new de facto identity of Spain, which sought to delegitimize the national identity constructed by the fascist regime. This idea, nevertheless, was linked to Ortega y Gasset's 'constitutional nationalism' of the early twentieth century (Flynn, 2001: 710). In any event, this unity with plurality consisted of granting powers to the various regional governments in Spain.

The Spanish territory was divided into seventeen autonomous communities, 'each with its own statute of autonomy and regional assembly, making the unity of the Spanish nation even more problematic' (Stapell, 2007: 175). The decentralization of power allowed the various regions to define themselves. Many regions in Spain, notably the Basque Country and Catalonia, used language, tradition, and ethnic affinity as tokens to redefine themselves. Devolution as a political strategy did not immediately appease the more extremist factions of the separatist regions; the repressive past of the Francoist regime could not be so easily forgotten. 
The Euskadi ta Askatasuna (ETA), in the Basque Country, became 'the organization that came to embody the radical variant of nationalism because of its commitment to independence and nothing less' (Jeram, 2013: 1776). For years to follow, Catalans and Basques would fight to seek independence from Spain. However, since Spain became a new democracy, an unspoken perception of a shared belonging has always been present. Article 2 of the 1978 Spanish Constitution refers to 'the indissoluble unity of the Spanish nation'. As Garcia Casado (1987: 43) argued back, 'the Spanish nation exists neither as a cultural reality nor a community of individuals with a strong and homogenous national identification'. Prior to the ascension of Spain to the European Union in 1986, the narratives of inclusion and exclusion were weak and not compelling enough to strongly imagine a univocal horizontal fraternity. In other words, competing discourses for nation building had not produced the necessary 'torque' for national unity that could make the Spanish people forget the legacy of the past.

\section{WHO BELONGS TO THE NATION?}

The ascension of Spain into the European Union marked a new phase of nation building. Spain quickly experienced rapid economic, social, and political progress, becoming the preferred destination of immigrants from around the world. Between 2000 and 2009 , the foreign-born population more than quadrupled, 'rising from under 1.5 million to over 6.5 million. During this period, the immigrant share of the total population grew from just under 4 percent to almost 14 percent' (Arango, 2013: 2).

The rapid arrival of immigrants, particularly from poorer countries, has made visible many changes in Spanish society. Immigration has increasingly inspired xenophobic incidents and adverse attitudes toward migrants (Checa Olmos and Arjona Garrido, 2013). Contemporary global migratory movements have brought new challenges to the question of national identity in Spain and to Spanish immigration law. The arrival of immigrants from poorer countries has facilitated competing discourses of exclusion and inclusion, strongly impacting cultural unity in Spain. 
Since Spain transitioned to democracy, two main political parties have shaped its politics - the Spanish Socialist Workers' Party (PSOE) and Partido Popular (PP) (Calavita, 2005). Aspiring to become a new member of the EU and without experience or worries about immigration, PSOE created the first immigration law in 1985, but it only served to 'placate the other members of the EU that were concerned that it would serve as the entry point into Europe for unwanted immigrants' (Jeram, 2013: 1777).

The law was very restrictive; it did not provide a legal avenue of immigration into Spain and imposed sanctions against irregular immigration. Various regions of Spain reacted against this restrictive law for various reasons. The Spanish cities of Ceuta and Melilla in North Africa argued that a third of their populations were of Moroccan origin and the law had turned them into illegal immigrants. After many protests and demands for nationalization, a special process of access to citizenship was granted to both cities (González-Enríquez, 2009: 140).

Early in the history of immigration in Spain, the 1985 law already made a distinction between two large groups: Latin Americans, Philippians, Andorrans, Equatorial Guineans, and Sephardic Jews, who had perceived cultural and historical ties with Spain; and those who came from Africa, particularly Moroccans. The first group was required to reside in Spain for two years prior to applying for legal citizenship, whereas people in the second group were perceived as lacking such imaginary historical and cultural connection and had a ten-year requirement. The exclusion of Moroccans as people with no historical link to Spain is quite ironic because Morocco was a Spanish protectorate from 1912 to 1956 (Rius Sant, 2007). This form of discrimination is consistent with more contemporary forms of racism, or neo-racism, in which cultural incompatibility constitutes the basis for exclusion and unequal access to rights.

By the 1990s, fear of a perceived 'avalanche' of immigrants coming to Spain, spread by the media and government officials, was becoming of increasing concern in Spain. As immigration continued to grow, the nationalist, separatist region of Catalonia increasingly complained that the law was too restrictive and did not provide enough social rights for the immigrant community. The 
main Catalan nationalist party, Convergencia i Unio (CiU) feared that it would lose its identity, so it demanded a more inclusive law and pressured Parliament in 1998 for change. They hoped to assimilate immigrants into the Catalonian region by teaching them their language and customs. The underlying belief was that immigrants' descendants would be, if assimilated, indistinguishable from the rest of the population (Castles and Davidson, 2000: 60).

By 2000, immigration was acknowledged as a permanent phenomenon and soon became an important concern for the entire Spanish society. With the objective of controlling undesirable social consequences unleashed by unregulated, non-European immigrants coming particularly from Latin America and Sub-Saharan Africa, the center-left PSOE proposed the more socially inclusive law 4/2000. Driven by fears grounded in social change, the leftist-leaning law afforded many political and social rights to immigrants, such as the right to education, health, and social security, regardless of an immigrant's legality. It additionally afforded political rights of association, union membership, and demonstration, and made mandatory that the state provide documented justification when denying a visa request (Jeram, 2013: 1778). The discourse of affording more rights to immigrants was framed around 'the possibility of immigrants spreading contagious diseases (there was talk of tuberculosis reappearing), and averting juvenile delinquency among adolescent immigrants not enrolled in school' (González-Enríquez, 2009: 142).

The new law was created with a coalition of non-governing parties and was more socially and politically inclusive than desired by the governing party, the center-right PP. Without a solid view on immigration, and lacking a majority in Parliament, the PP was forced to go along with the new law. Without much experience dealing with immigration and with a newly democratic culture of inclusion, Spaniards and the media reacted in a positive way to this law; however, affording rights to immigrants to mitigate perceived threats to its society and identity did not last long - this was not the preferred policy of the PP.

The socialist-party-driven law 4/2000 was conceived between 1985 and 1996, a few years before the Tampere European Council 
of 1999. This Council marked the initiation of a global comprehensive approach to migration in Europe. The Council established three pillars to tackle the increasing preoccupation with immigration in Europe: Social integration of immigrants; control of migratory flows; and cooperation to develop countries from which immigration originates, with the goal of reducing immigration to European countries (Marin Sanchez, 2010: 3).

The increased rate at which immigrants from less-developed countries were migrating to Spain was a big concern for Europe. Spain, now a member of the European Union, was perceived by other EU members as a key player in the policies of immigration control. Located at the southern tip of Europe, Spain is considered the door to the rest of Europe. The arrival of immigrants to Europe via Spain from Latin America and Africa gave rise to a debate that led to the creation of $8 / 2000$, a more repressive immigration reform law.

The new and much more restrictive law 8/2000 was approved immediately after the center-right PP won the general elections in March 2000 with an absolute majority. The new law aimed to deal with immigration and its imminent threat by prohibiting the fundamental civil liberties of right to association, demonstration, and unionizing for all legal immigrants in Spain. It was not until 2007 that these provisions were found unconstitutional and corrected in the new law 2/2009, while the left-center PSOE controlled the government. In addition, the law 8/2000 reintroduced the expulsion of immigrants as punishment for staying without a permit and increased the requirement from two to five years that an 'irregular migrant had to spend in Spain in order to regularize their stay permit' (González-Enríquez, 2009: 144).

During this time, from 2000 to 2007, the attitudes of Spaniards toward immigration were increasingly becoming more adverse. It was found that 'anti-immigrant feelings has taken place ...the main variables that explain[ed] this increase... [were] on the one hand, the threat defined by the number of perceived immigrants and the loss of national identity and, on the other hand, the competition for the economic and social resources and the state investment destined to immigration' (Checa Olmos and Arjona Garrido, 2013: 
1). Vis-à-vis other European countries, however, Spanish attitudes were comparatively positive toward immigrants.

Around 2007, the government became increasingly more restrictive as a result of the so-called 'crisis of the Cayucos (a kind of small boat), when in the summer of 2006 some 25,000 undocumented migrants arrived in the Canary Islands aboard such vessels after sailing from the coast of West Africa' (González-Enríquez, 2009: 150). This was no isolated incident. The deep economic crisis that was emerging became apparent around 2008 when economic indicators revealed very high unemployment. At the same time the EU pressed for 'greater collaboration in fighting illegal immigration from Africa' (151; see also Marin Sanchez, 2010). The economic crisis propelled the discourse of immigration, and both political parties promised to be more restrictive toward immigration if the crisis persisted.

Prior to the 2008 economic crisis, surveys indicated that Spaniards widely accepted the necessity of having immigration as a means to propel economic growth. This view was spread widely by both dominant political parties and the media. Spaniards' attitudes, as well as the many policies of the nation, broadly reflected the unfounded belief that immigrants were not coming to stay permanently, but to take unwanted jobs (Arango, 2013). Immigrants were viewed as a labor force, not as people who wanted to find a permanent home in Spain. In a personal interview conducted in 2007 with Guervos Maillo, the sub-director of the Spanish Labor Ministry and Immigration, the argument was that 'Queremos que vengan extranjeros pero solo a rellenar los huecos que tenemos libres de mano de obra' (We want foreigners to come to Spain, but only to fill those job openings that require workers).

Narratives alluding to the filling of unwanted jobs, in conjunction with the desire of Spain to become an inclusive democracy, may explain why Spanish attitudes were more accepting of immigrants when compared with their European counterparts. These perceptions and attitudes laid the foundation for integrating immigrants into Spanish society. The office of Secretary General for Immigration and Emigration was not created until 2011. Immigration issues before then were handled by the Ministry of Labor, which later became 
the Ministry of Labor and Immigration, when immigrants began to arrive in Spain. Treating immigrants in great part as merely a labor force did not facilitate access to equal opportunities. Treating immigrants as labor reinforced the idea that they would eventually go back to their country of origin after their work was finished, resulting in exclusion rather than integration and preserving a perceived native ethno-cultural homogeneity in the nation.

As the economic crisis pushed the native population's unemployment rate over 34 percent, it could no longer be claimed that immigrant workers were needed or that they were good for the economy. The increasing realization that immigration was permanent drove exclusionist discourses that openly viewed immigration as a phenomenon that should not be allowed to bring significant social and cultural change to the nation (Castles and Davidson, 2000). During the 2011 elections, the conservative PP viewed this as an opportunity to redefine its nationalist-leaning position on the question of the Spanish identity. Not only did PP promise tougher immigration policies, but it also promised to include assimilationists and exclusionary policies for the integration and expulsion of immigrants if elected. In his various speeches, Rajoy, the leader of $\mathrm{PP}$, was clear in stating that he would create tougher policies than those espoused by his predecessor Jose Luis Zapatero. He promised to introduce an 'integration test'.

With their landslide victory in the 2011 elections, the PP introduced an integration test that requires immigrants who want to legally stay in Spain for longer than a year to demonstrate that they know Spanish customs, norms, and language. Those applying for citizenship must demonstrate similar competencies. Up until then the Spanish notion of citizenship 'had not imposed a homogenous identity, but it had refrained from proclaiming that multiculturalism and diversity are sources of enrichment for Spanish society' (Jeram, 2013: 1782). This test has already been challenged in court.

La Audiencia Nacional has recently denied citizenship to an Ecuadorian citizen residing in Spain. The court denied his application for citizenship because he could not answer enough basic questions about Spain. The court ruled that social integration consists of more than just knowing Spanish, the native language 
of the applicant (El Pais, 2013). Following similar recent European trends, immigration policies in Spain now center on integration, assimilation, border control, tougher sentences for smuggling immigrants, and suppression of health benefits for illegal immigrants (González-Enríquez, 2009: 151). Immigrants will now have access only to emergency medical services. The overall goal, according to the administration, is halting new arrivals of immigrants so long as the economic crisis continues.

In sum, discourses of inclusion and exclusion coexist in the Spanish nation. Discourses of immigration alluding to threat and exclusion have become the center for the re-imagining of a Spanish national identity, indicating that a sense of pride in Spanishness can be identified and arguably is growing in Spain. While what constitutes Spanishness remains controversial, the Spanish self consists of a somewhat post-modern, diverse, homogenous identity that shares a common cultural heritage (Stapell, 2007). The idea of a homogenous Spanishness that coexists with internal regional diversity gains strength when contrasted with an imaginary 'other' labeled as immigrant who does not share an imaginary common historical and cultural heritage.

\section{CONCLUSION}

The development and persistence of peripheral nationalisms at the end of the nineteenth century does not prove that an overarching national identity cannot be identified in Spain. As Álvarez Junco (2002: 15) argues, the Basque and Catalonian nationalisms are only the product of the 'weak effort to nationalize the masses, or the incomplete nation-building process, in Spanish-Castilian terms, during the nineteenth century'. In other words, building a nation that excludes certain regional, ethnic expressions has the opposite effect. Nation building is a fluid and always evolving process. In the case of Spain, the exclusion of non-Catholics first, followed by a rejection of liberal values, and later exclusion of sub-national identities - these have served to re-imagine various notions of Spanishness, yet none have led to successful nation-building in Spain. 
With the arrival of immigrants and the ascension of Spain into the European Union, a clear group represented as 'not belonging' to the cultural milieu of Spain can now more easily be identified. Who belongs to 'us'? And who are we anyway? These questions have recently become once again of great importance for the Spanish nation. Competing discourses of immigration challenge to some extent Anderson's 1983 argument on the process of nation-formation as an imagined 'horizontal comradeship'. The Spanish state has apparently become conflicted with the idea of imagining a conventional 'horizontal fraternity'. The ultimate goal of the state is to find a positive unified self against the other. For this reason, practices and argumentations alluding to assimilation co-exist with those of exclusion. In addition, and most importantly, the Spanish 'self' is constructed as an entity with a shared historical and cultural 'belongingness'.

Re-imagining a national unity entails forging a solidarity based on 'belongingness' and/or 'horizontal comradeship' while simultaneously excluding certain groups. In creating a sense of unity in contemporary Spain, it was essential to construct immigrants as a threat to the economy and the cultural heritage of Spain to forge a sense of national unity capable of bridging across regional identities. To build national cohesion, as Anthony Marx (2003: 75) suggests, a form of exclusion must have enough 'torque' to cut across regional divides; the exclusion of selective groups of immigrants in Spain appears to have such strength or 'torque'.

At the same time, not all immigrant groups are equally excluded from joining the national unity. Given the fluidity of the nation to re-imagine itself, practices of inclusion and assimilation of excluded groups provide small open spaces to incorporate selected immigrants into this fraternal horizontal unity. This dynamism facilitates space for the constant re-imaging of the nation.

Incorporating immigrants into the horizontal or fraternally imagined nation is a highly selective process, for not all immigrants will qualify to be assimilated, and the process is complex. But above all, Breuilly (1982: 1-2) reminds us that nationalism is about politics, and politics is about power, and power, 'in the modern world is principally about control of the state'. 


\section{POVOS, ESTADOS E INSURGÊNCIA ISLÂMICA NA ÁFRICA}

HERBERT EKWE-EKWE

Resumo: O autor reflete sobre a incapacidade do Estado na África em prover segurança e fornecer serviços sociais básicos à maioria da população. Argumenta que o "Estado de Berlim" pós-conquista europeia está sob crescente pressão de povos ou nações que desejam se tornar independentes. O mundo terá que lidar com um mapa da África em constante mutação, baseado nos movimentos de independência, que não são em essência islâmicos.

Palavras-chave: Estado de Berlim; África; Movimentos de Independência; Insurgência Islâmica

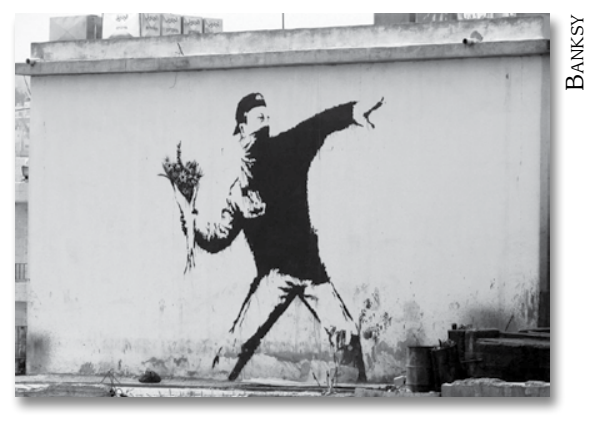

\section{PEOPLES, STATES AND ISLAMIC INSURGENCY IN AFRICA}

\section{Herbert EKwe-EKwE}

Pesquisador independente na área de relações internacionais, especialista em genocídios, conflitos e guerras na África pós-colonial.

hekweekwe@hotmail.com
Abstract: The author discusses the African States' inability to provide security and basic social services to the majority of the population. He argues that the "State of Berlin" created by the European conquest is still under the growing pressure of peoples or 'nations' that want to become independent. The world will have to deal with an African map in constant change based on independence movements that are not Islamic in essence.

Keywords: Berlin State; Africa; Independence Movements; Islamic Insurgency

RECEBIDO EM $17-04-2015$

APROVADO EM $12-05-2015$ 